\title{
CULTURAL SOCIETIES AND LOCAL COMMUNITY MUSEUMS: A CASE STUDY OF A PARTICIPATIVE MUSEUM IN GREECE
}

\begin{abstract}
This paper focuses on the role of cultural societies in the establishment of regional museums in Greece. It uses as a case study the Museum of Refugee Memory on the island of Lesvos, a small local institution, created and supported entirely by a local cultural society; the museum, despite its size and professional shortcomings, has become a vehicle of social cohesion and an expression of a distinct local identity. This paper argues that this museum forms an example of a grass-roots museum initiative that deserves to be studied and even copied, since its operation provides an alternative model of cultural heritage and museum management that reaches to the local communities and resources instead of national or top-down ones. First, it presents in brief the development of the local cultural institutions policy in Greece and then it turns its attention to the case study and presents the information gathered through in situ research, multiple visits and interviews, in order to argue, in the final part, about the importance and role of such institutions.
\end{abstract}

SŁOWA KLUCZE: stowarzyszenia kulturalne, muzeum społeczności lokalnej, muzeum uczestniczące, Grecja, Muzeum Pamięci Uchodźców

KEY WORDS: cultural societies, local community museum, participative museum, Greece, Museum of Refugee Memory

\section{Introduction: Local communities and resources}

The cultural identity of regional and local communities is shaped according to a series of parameters that relate to the history and traditions of the region, contemporary creation taking place there, the natural environment, the civic or rural social stratification, and so on. Since identity is a major motive for the creation of heritage, it is no surprise that heritage is the principal instrument for shaping distinctive local 
representations of place, "which can be exploited for external promotion as well as in strengthening the identification of inhabitants with their localities."1

The social, political and economic uses of heritage are all visible at the local scale. Local administrations need as much as national governments to justify their rule and to establish the historical continuity of their region as a form of legitimacy for the area, as well as for themselves. Indeed, the relation of local people with their local entities makes the difference between a successful devolved management system and an unsuccessful one. In order to achieve cohesion of local societies (or minimize conflict between them), regional authorities rely on the inclusiveness and representativeness of local heritage. Often, to this end different cultural groups or citizens' initiatives collaborate with regional authorities and ensure representation of interests and views.

Towns, villages and regions also use heritage elements within local economic strategies in various ways. It seems to be a common ground the fact that in order to promote a place, to make it 'desirable' and 'consumable' by both tourists and potential new inhabitants, and therefore develop economic activities, heritage is essential. ${ }^{2}$ Every effort is made to create a distinct cultural identity, which will then be used for multiple reasons.

Museums are parts of such efforts. Therefore, they have been - and still are - in the center of many efforts to establish local identity and to provide means for promoting the 'locale', both internally - within the community - and externally. The study of these efforts is important for many reasons: it allows researchers to understand the relation of local communities to their past, the dynamics within communities, the main collective projections to the future. The role of the authorities, both national and regional is also important in understanding both the museums, and the relation of the communities with their past and present. On the other hand, from a museum perspective, it is possible by studying these institutions to understand how museums can become vehicles of social cohesion, of collaboration and identity formation.

Taking into account all the above, in this paper I will focus in particular on the role of cultural societies in the establishment of regional museums in Greece, an issue that has not been explored in depth so far. I will use as a case-study the Museum of Refugee Memory in Lesvos, since this is a small local museum created and supported entirely by a local cultural society and it has become a vehicle of social cohesion and an expression of a distinct local identity. I will argue that this museum forms an example of a grass-roots museum initiative that deserves to be studied, and copied, since its operation provides an alternative model of cultural heritage and museum management that reaches in the local communities and resources instead of in national or top-down ones. In the parts that follow, I will present in brief how this issue has been dealt with in Greece and then I will turn to the case study and present the infor-

${ }^{1}$ B. Graham, G.J. Ashworth, J.E. Tunbridge, A Geography of Heritage: Power, Culture and Economy, London 2000, p. 204.

2 Ibidem. 
mation gathered by in situ research, multiple visits and interviews, in order to argue, in the final part, about the importance and role of such institutions.

\section{Cultural Societies and Museums in Greece}

In Greece, cultural societies, i.e. groups of people sharing similar cultural concerns and/or place of origin, have been active in various heritage projects, including museums since the last part of the $19^{\text {th }}$ century. Some of the most important national museums today are the results of the initiative of cultural societies, as for instance the National Historical Museum of Athens, which was established and is still run by the Historical and Ethnological Society of Greece, ${ }^{3}$ or the Byzantine and Christian Museum, which is the result of the initiative of the Christian Archaeological Society. ${ }^{4}$ On a local level also, cultural societies have been active in the creation of institutions, mainly local museums of ethnology, history or art. ${ }^{5}$ The number of these societies and their involvement with the establishment of cultural institutions started to grow in the late 1970s. According to the information gathered in 1979 by the National Center of Social Research on behalf of the Ministry of Culture, until that year there were 169 local (ethnographic) ${ }^{6}$ museums/collections recorded in Greece, whereas 20 years later, in the 1990 s the number has doubled with almost 400 local institutions in place. Currently they are estimated to almost $800 .^{7}$ Most of these institutions are the result of the activity of local groups of people.

The reasons that were offered to explain why local communities, individuals and/ or local cultural organizations decided to pursue the creation of these museums are usually twofold: some researchers categorize the decision to create museums as a "reaction against industrialization and urbanization of life, the increasing transformation

${ }^{3}$ For information see the museum's website: http://www.nhmuseum.gr/el/poioi-eimaste/i-istoriki-kai-ethnologiki-etaireia-tis-ellados/ [access: 2.01.2016].

${ }^{4}$ For the history of the Society see the website: http://www.chae.gr/101.html [access: 22.12.2015].

${ }_{5}$ See also: G. Gizelis, I. Antonakopoulou, O. Gardiki, E. Kalpoutzi, Ch. Laskaratou, Organisation and Space Distribution of Greek Folklore Museums and Collections, Report, 1979, Vol. 1, Athens 1979 (in Greek); Ch. Ntaflou, Donateurs et musées dans la Grèce contemporaine [in:] D. Poulot (Ed.), Goûts privés et enjeux publics dans la patrimonialisation XVIIIe-XXIe siècle, Sorbonne Publications/coll. Histo. Art - 4, 2012, pp. 139-160.

${ }^{6}$ According to the Greek legislation, all antiquities belong to the State; therefore, archaeological museums are always national - only two exceptions, the Benaki Museum and the Goulandris Museum of Cycladic Art - and they are created by the State. This is the reason, local institutions usually focus on history, ethnography, natural history and art. For the Greek legislation regarding antiquities and museums, see: D. Voudouri, State and Museums: The institutional framework of archaeological museums, Athens 2003 (in Greek).

${ }^{7} \mathrm{~K}$. Bada, Formation and promotion of locality as a characteristic of museums of traditional culture, Paper presented in Scientific Conference "Research, Promotion and Management of small places. The example of the rural culture of Tzoumerka $\left(15^{\text {th }}-20^{\text {th }}\right.$ cent.)", Matsouki Ioanninon 2013 (in Greek). 
of rural areas and the subsequent mobility of rural population towards the cities." ${ }^{\prime 8}$ In other words, nostalgia of the traditional ways of life, along with a sense of loss of identity, fear of homogenization and probably estrangement in the large urban environments led to the decision to create local institutions that would allow for the construction of an "imagined community", 9 not of a national, but of a local character.

From another point of view, the establishment of local cultural institutions has been the result of nationalism, as they served the purpose of arguing for the importance of locality and of the "authentic" character of a group of people that would allow for differentiating them from "others." ${ }^{10}$ In the Greek case in particular, the ethnographic remains of the recent past became understood as the last step in a long journey, since they were treated as material testimonies of the continuity of the Greek nation from antiquity to the present day. ${ }^{11}$

In most cases, local cultural institutions aim to address both identity issues and issues of local development, since they provide reasons for visiting this particular part of the country, and therefore a means of economic development. ${ }^{12}$ These institutions have been thus considered an investment in the economic development of the region, since they are expected to become tourist destinations, to provide reasons for more prolonged stay in the area and, therefore, to increase the economic impact of tourism.

The role of the state cultural policy in this movement has been important. Already at the end of the 1970s, and with particular force after 1981, because of the then new socialist government, the Ministry of Culture encouraged and financed these efforts on a local and regional level. ${ }^{13}$ On the one hand, such material and ethical encouragement was meant to empower the regions and to respond to a well-identified need ${ }^{14}$ for a new cultural policy, more inclusive, that would allow for a complex and participatory model of cultural development. On the other hand, such efforts seemed to satisfy local communities, since they allowed for financing various cultural projects and provided means for touristic development. The institutions established locally were expected to be financed by the State and to be part of a state touristic policy. In other words, despite the fact that they were established by local cultural societies, these institutions were still part of a state policy, a top-down approach to culture and museums that were considered a vehicle of economic development, following the state plan. But, the plan did not work that well: the number alone of these institutions made it impossible for the State to support them and as a result most of

8 A. Economou, Material Culture: Theory, methodology, valorization, Athens 2014, p. 186 (in Greek).

9 The term was coined by B. Anderson, Imagined Communities. Reflections on the Origins and Spread of Nationalism, Verso 2006 (revised edition).

10 See: G. Gizelis et al., op.cit.

${ }^{11}$ For discussion see: T. Hadjinikolaou, Introduction [in:] C. Gougouli, T. Hadjinikolaou (Eds.), Special Volume: Museums and Folk Culture, "Ethnographica" 2003, 12-13, pp. 11-26 (in Greek).

${ }^{12}$ See: note 7.

13 See: note 10.

${ }^{14}$ E. Fessa-Emmanouil, The problem of cultural policy in Greece, "Issues of Space \& Arts" 1978, 9, pp. 59-65 (in Greek). 
these are either closed today because of lack of personnel or, literally, half-surviving, in the sense of being open for only part of the week or of the year. They rely mostly on volunteers and usually they lack in professional expertise. In addition, they have not managed to gain the support of their community in the sense of its actual involvement in them and to a large extent they remain alien to local people, who think of them as appropriate for visitors alone. So, it is necessary to re-examine this model of establishment and support of these institutions and to put their social and economic role into examination.

In this paper, I argue that there is another direction for these local institutions that emphasizes their role not as local touristic resources, alone, not as part of a state project to empower the regions, but as forces that encourage creativity, identity-building, community-enhancement, participatory creation, cultural sustainability. In this sense, their primary audience is not the tourists, but local communities, which participate in their creation and their development, which identify themselves through these institutions, which support local development in a more sustainable way and long-term perspective. I argue that instead of local museums, we should strive towards grassroots, local community, participative museums.

I will use as a case study the museums of the island of Lesvos, and in particular the Museum of Refugee Memory in the little village of Skala Loutron. Before I move on to the discussion of the case study, I will present in brief the island and its communities.

\section{The island of Lesvos, its communities and institutions}

The island of Lesvos is located in the north Aegean Sea; it has a population of almost 120,000 people and it is the third largest island of Greece (after Crete and Euboea). It is located just across the borders with Turkey, on the Asia Minor coast. In this coast a large Greek Orthodox population lived until 1922, when as a result of the collapse of the Ottoman Empire and its replacement by the modern Turkish state (1923), they were forced to leave. The population of Lesvos today consists of a large number of descendants of those refugees, who came to the island during the violent events of expulsion in 1922 and formed their communities, as the one in Skala Loutron that forms the case study of this article. In some cases the newcomers found the new land unwelcoming, a fact that made these communities to form even stronger links between their members. In many ways, they still feel themselves as diasporic communities, in the sense of having experienced forced movement from their place of origin. These events are rarely one-sided though: Muslim inhabitants of the island were also forced to leave in the exchange of populations that took place in 1923, after the Lausanne Convention. ${ }^{15}$

15 The island of Lesvos became quite well-known internationally in 2015 as one of the islands that have been receiving large numbers of Syrian refugees. The personal experiences and family mem- 
According to the most recent research, ${ }^{16}$ there are 35 museums on the island. ${ }^{17}$ Five of them have been established by the State and are run either directly or indirectly by the Ministry of Culture - although the initiative for the creation of two of them has been private, by a local man, Stratis Eleftheriadis-Teriade, who donated his collection to his home island and initiated the establishment of the homonymous museum,$^{18}$ today run under the auspices of the Ministry of Culture, and the Theophilos Museum, currently run by the Municipality. Local authorities, i.e. the Municipality, have established and run six of the institutions; the Church has responsibility for seven museums, whereas five more are individual or corporate initiatives. This leaves 12 local museums which have been established and are run by some form of local cultural organization. These range from the Women's Society of the Village of Sykamia (in the north part of the island), to the cultural association "Archipelagos," which was established in 1977 by a group of intellectuals in order to contribute through culture and quality touristic development to "shielding off through culture the nationally sensitive Aegean sea area." 19

Having set the framework, I will now turn to the Museum of Refugee Memory.

\section{The Museum of Refugee Memory}

The Museum of Refugee Memory is housed in the Primary School Building of the village Skala Loutron, which was given by the regional authorities and the State to the Society of Asia Minor People of Skala Loutron, named "The Dolphin" in 2003, after the school was closed because there were not enough primary school pupils in the village anymore. There had been a debate between the Society and the then local authorities that also wanted the school building in order to turn it into a cultural centre. The Society had been established in 1990 and it was the initiative of local fishermen; it had been already very active organizing music and dance events, folkloric performances, theatre plays, memory nights and so on. All these activities, as well as the Museum, are part of the wish of the community "to retrace their roots and to en-

ories of the inhabitants of the island have been very important in terms of defining the hospitality, empathy and compassion with which these waves of refugees have been, and are, received and aided.

${ }_{16}$ The research was carried out and published by Eolis - Company of the Cultural Development of Lesvos, Guide to the Museums of Lesvos. Museums, Collections, Exhibitions, Libraries, Galleries, Mytilene 2006.

${ }_{17}$ Just for reasons of comparison, in the 1979 research already mentioned above (G. Gizelis et. al., op.cit.) only 8 of those are mentioned. Of course, the 1979 research did not include the three archaeological institutions - the first of which (Old Archaeological Museum) was established in 1935, the second (New Archaeological Museum) was inaugurated in 1995, while the third (the Archaeological Collection of Eressos) has its roots in the Ottoman period of the island.

${ }_{18}$ Museum-Library Stratis Eleftheriadis-Teriade.

19 V. Christidou, Olive-Press-Museum: a journey in time, "Emprosnet" 2009 (in Greek), http:// www.emprosnet.gr/emprosnet-archive/619acdae-5dbb-46cc-af63-ef878c3f8555 [access: 22.12.2015]. 
courage/empower Asia Minor memories and identity ... now that there are 5-6 of the early refugees still around." 20

In 1922, a group of refugees, mostly from the town of Focaea in the now Turkish coast, that arrived in Lesvos after the population exchange and the dramatic events in the cities of the coast, took refuge in the area of Loutra, some of them in the village, and some others - most of them - in old deserted commercial storage spaces and village houses in Skala Loutron, an uninhabited area, with very basic port facilities and two olive press workshops. This arrangement lasted for 8 years, until 1931, when each of the 25 refugee families was allocated a house of two rooms that had been built by the state in an open area nearby, called Vatsina. Thus, the little village known today as Skala Loutron was established. In 1931 there must have been 160 inhabitants; today there are 300 locals, there is a local council and the village is run by the $\mathrm{Mu}$ nicipality of Lesvos. $80 \%$ of the population today are offspring of these first refugee inhabitants while "the fifth generation of refugees," as they call themselves, has been born. The strong impact of the refugee identity in the inhabitants, but also all members of the families in the area, becomes obvious from the above phrase.

The idea for the creation of the Museum belongs to Stavros Valachis, a school teacher, who was influenced, as he says, from his visit to the Museum of New Karvali in the area of Kavala (in the north of Greece). ${ }^{21}$ There, a similar diasporic community has also established a local community museum. Valachis, along with the President of the Society, undertook the responsibility of establishing the Museum and of supervising all the works necessary for its creation, which lasted for 3 years. Financed by the Society, a group of local people, men and women, repaired and refurbished the building of the 130 square metres, working long hours in order to create the gallery where the collection is currently displayed. Those responsible describe the process as follows:

Setting up the museum, the appraisal, the plans, the materials, the murals, were all the products of our own work and of the offerings of members of the Society. Apart from lower costs, the main reason this was so, has been that we wanted to feel the Museum as our own; we wanted to live the experience of setting up a museum and everything to be a product of love and offering. We did not want some stranger to be involved, somebody who would not feel the value of our Museum for us. ${ }^{22}$

The Museum was inaugurated in 2006 (Ill. 1 and 2) and since then it has a steady number of visitors, mainly local school groups, the people of the village and the tourists staying in a nearby touristic complex. They gather at the Museum and in the yard to enjoy cultural activities of all sorts, to bring something more for the museum collection that was found in the closet or in the storage, but also in order to continue offering their services, since the cases need to be repaired and completed, the space needs to be cleaned, the mural maps - which are the central exhibits - need additions to be made.

\footnotetext{
${ }^{20}$ Interview to D. Psirras, 2008.

${ }^{21}$ S. Valachis, interview to the author, 2009.

22 Interview to D. Psirras, 2008.
} 


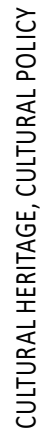

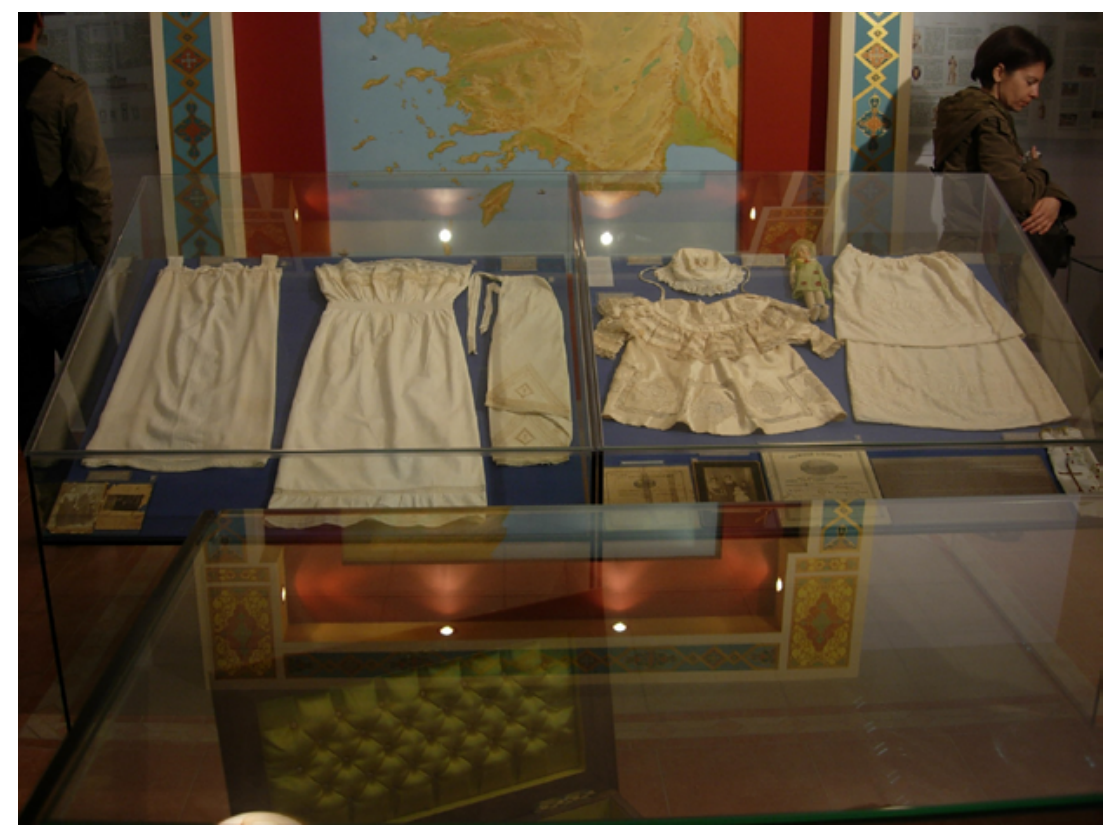

III. 1. Exhibition cases in front of a map. Museum of Refugee Memory. Photo by A. Bounia

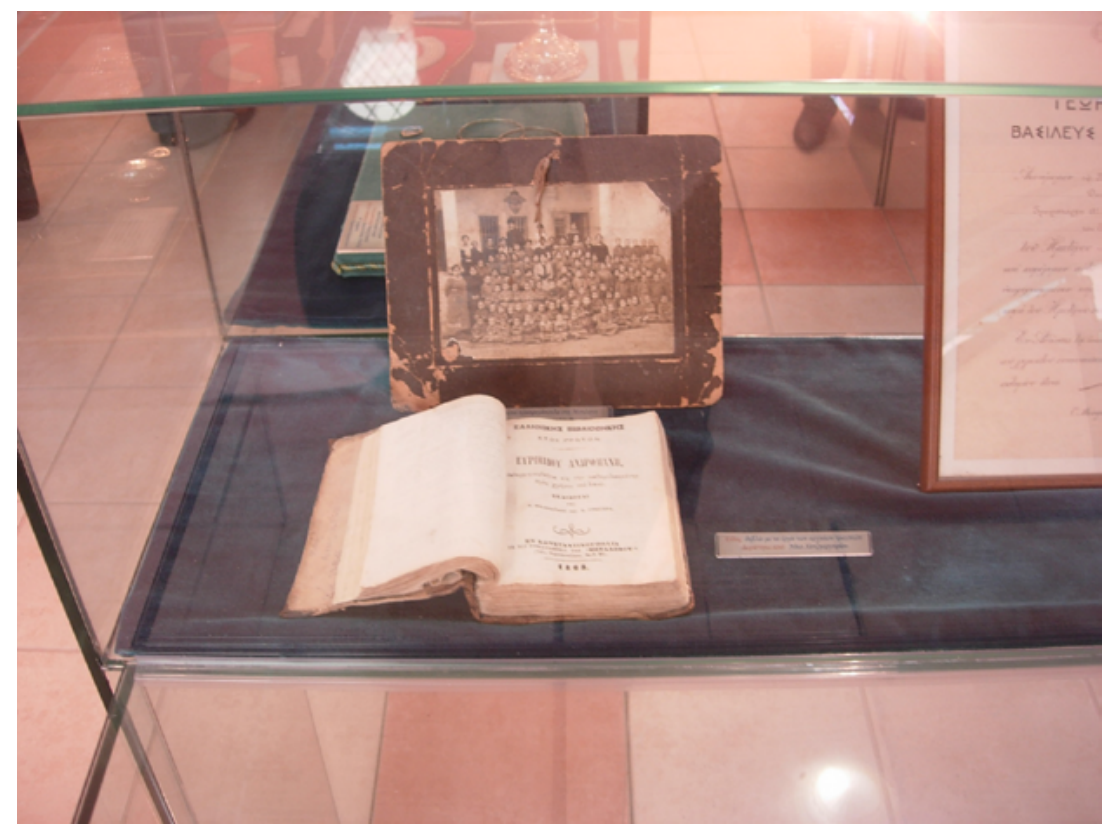

III. 2. Personal objects exhibited in the Museum of Refugee Memory. Photo by A. Bounia 
The exhibition consists of a collection of artefacts that belong to different categories; almost all objects are donated by the local people. Some other artefacts are loaned to the Museum for short-term or long-term periods. For every object, there is a label where the name of the owner, the name of the donor and the place this object comes from are mentioned... Thus, even in the cases that the object is donated, it remains, symbolically, the property of the donor, as a personal reminder - an "inalienable possession", in the term of Annette Weiner (1992). ${ }^{23}$

The basic axis of the exhibition though is the construction of two large-scale mural maps that decorate the main walls of the Museum: the larger one is a map of Greece and Anatolia, including present day Turkey to Kurdistan and Iraq. The smaller one is a map of the Aegean islands and the now Turkish coast. According to the designer of the maps, the local school-teacher, the map is the only visual aid that makes visible the extent of the events of dislocation and population exchange. On the small map are marked the first ancient Greek colonies up to the Byzantine era; on the larger one, all villages, towns and cities which once had Greek Orthodox population. The maps are "active", in the sense that they are constantly filled in with more names added by the villagers, every time they read or learn about a new place, or by visitors who have similar memories or experiences and share them with the museum people during their visit. Every piece of information is cross-checked with the Centre of Asia Minor Hellenism in Athens, before it finds its position on the maps.

Despite the fact that the collection consists of many ethnographic objects, the ethnographic interest is limited. The aesthetic value of the objects is also secondary; primary importance has their historic value as heirlooms and their ability to trigger memory and storytelling by either visitors or donors.

Finally, a very important case in the Museum is the one devoted to Muslims that used to live in Greece, and in Lesvos in particular, and they were also forced to move to the other side of the coast (Turkey) because of the same events. They were also forced to leave their homes and become refugees. The Museum cases consist of objects that were accidentally found by the villagers, who then donated them to the Museum in order to make this addition that complements in the best possible way the historical spirit and the wish to energize memory; this case is also a tangible proof of the understanding and deep humanity of the people, mostly fishermen, housewives and craftsmen that comprise the population of the village.

Of course, there are many plans for the future: the collection grows; there are plans for acquiring on behalf of the Society the last surviving refugee house of the village, which is a listed building by the Ministry of Culture, in order to house there the library and the historical archive of the Museum. At the same time, the design of a new museum building is planned, funded by the Society. The new generation of the village consists of young well-educated people, who share the interest of their families for the Museum and also want to help. Despite the fact that they do not live in the village anymore, every summer or every time they visit, they go by the Museum, often to meet a member of the family who is there attending to something, or in order to join one of the events, concert, theatre, performance, music taking place in the yard.

${ }^{23}$ A. Weiner, Inalienable Possessions: the paradox of keeping-while giving, Berkeley 1992. 


\section{Discussion and Conclusions}

Up to this day, in Greece when we refer to small regional or local museums, created not by the State but by local societies, local authorities, the church, etc., we usually insist on their shortcomings: lack of professionalism, lack of special preservation conditions for their collections, need for further financing and other support by the state and so on. The small Museum of Refugee Memory in Skala Loutron invites us to focus not on the problems or the shortcomings, but on a very important advantage of these museums: their relation to local communities, the connection that makes ordinary people offer their heirlooms, their time, and their effort. This is a dynamic relationship, a relationship of inter-dependence that needs to be studied and copied. I argue that this is a relationship that creates social and cultural capital; it empowers societies; it leads to the creation of social responsibility, the wish to be involved in public life; it empowers and supports creativity, the sense of personal and communal value. The museum thus becomes a space of encouragement, where members of the community can acquire different categories of qualifications, mostly social, to acquire self-confidence, to take control and feel ready to contribute to the social and cultural life. Participation can thus become a lesson of democracy, since it makes the extent of social responsibility and personal involvement clear.

I believe that museums like the one I just described - and there are many like that in Greece, Europe and other parts of the world - offer a new model of local museums, the local community museum, which far from being a top-down institution, hoping to preserve what the state or even the local elites consider important and attract tourism and therefore new sources of income, are grassroots initiatives, that share the power to decide what is important for local heritage and what is not and focus on empowering the community before attracting tourism.

Community museums - in the European context as well as internationally - are important parameters of community sustainability since they allow for the creation of community capital. ${ }^{24} \mathrm{Far}$ from being peripheral in cultural policy development on a national and/or local level, these institutions are central in cultural policy planning. Natural, physical, economic, human, social and cultural forms of capital are included in and reinforced by these small, and often amateurish, institutions. Being grassroots initiatives, local community museums empower people and strengthen participation, which in turn encourages mutual respect for stories, resources, hopes and dreams. Besides being an expression of empathy for other people suffering the same pain, the Muslim refugees' case in the Museum of Skala Loutron is a clear example of such respect. Community museums are community-building tools that promote a sense of place, empowerment and public participation - all key components for a sustainable community development.

${ }^{24}$ For the term, see: A. Morris, Community capital: definition, [n.d.], http://www.learningtogive. org/resources/community-capital [access: 2.01.2016]. 
As Appadurai has argued, ${ }^{25}$ societies must do cultural work in order to create the local. Community museums encourage and are part of such cultural work, that creates a sense of locality and thus of belonging to a community. Rooting certain of their practices and locales to the past, helps the creation of legitimate claims for the present and the future. ${ }^{26}$ Especially in the case of diasporic communities, the need to develop heritage practices that would bind them both to their homeland and to the new places they are settled in, is real and pressing. ${ }^{27}$ The case of the small museum we discussed exemplifies in the most tangible manner this need, by offering to the community the framework within which to develop heritage practices that will afford them both social and cultural capital.

On another level, this small institution provides an alternative model to the one currently supported by Greek cultural policies, which are built on a top-down perspective, despite their often local descend. The reason of such a claim is the strong hegemony of the state, which by handling the financial resources and providing an academic supervision of these institutions has largely alienated the locals from their own resources, or marginalised their own interpretations. This is the reason that most of the local institutions of the country, even when they are open, are rarely visited during the winter - i.e. when tourists are not around.

Instead of thinking of them as amateurish attempts, a new cultural policy model should focus on the role and possibilities such museums offer, as they are more directly linked with a communal past instead of a constructed hegemonic vision of it. ${ }^{28}$ They are very successful in their communication, in the creation of a new understanding of museums as community spaces, as public spaces, which are simultaneously an extension of home. Is there a better investment in citizenship education? Is there a better aim for a cultural organisation? Is there a better description of the essence of cultural sustainability? They do offer an alternative perspective on museum making and heritage management and thus can help towards developing a new model of cultural sustainability that would allow and ensure not only their survival but also the survival of their communities' ethos and spirit.

I believe that governments and local authorities should develop a greater understanding and collaboration with small institutions like the one I described. They should aim to a mutually beneficial exchange: share know-how to receive interest, share with humility and a generous spirit to receive enthusiasm and creativity. This is the only way that real networks offering sustainable participative development for the future can develop. Further research on how these institutions are established and

${ }^{25}$ See: A. Appadurai, The globalisation of archaeology and heritage: a discussion with Arjun Appadurai, "Journal of Social Archaeology" 1999/2001, 1 (1), pp. 35-49.

${ }^{26}$ R. Harrison (Ed.), Understanding the Politics of Heritage, Manchester 2010.

27 P. Basu, Object diasporas, resourcing communities: Sierra Leonean collections in the global museumscape, "Museum Anthropology" 2011, 34 (1), pp. 28-42.

${ }^{28}$ E. Waterton, St. Watson, Heritage as a focus of research: past, present and new directions [in:] E. Waterton, St. Watson (Eds.), The Palgrave Handbook of Contemporary Heritage Research, London 2011. 
operate will provide all stakeholders with precious information that will allow them to build new models of local institutions, new models of citizens' involvement in culture, heritage and tradition.

\section{Bibliography}

Anderson B., Imagined Communities. Reflections on the Origins and Spread of Nationalism, Verso 2006 (revised edition).

Appadurai A., The globalisation of archaeology and heritage: a discussion with Arjun Appadurai, "Journal of Social Archaeology" 1999/2001, 1 (1), pp. 35-49.

Bada K., Formation and promotion of locality as a characteristic of museums of traditional culture, Paper presented in Scientific Conference "Research, Promotion and Management of small places. The example of the rural culture of Tzoumerka $\left(15^{\text {th }}-20^{\text {th }}\right.$ cent. $)$ ", Matsouki Ioanninon 2013 (in Greek).

Basu P., Object diasporas, resourcing communities: Sierra Leonean collections in the global museumscape, "Museum Anthropology" 2011, 34 (1), pp. 28-42.

Christidou V., Olive-Press-Museum: a journey in time, "Emprosnet" 2009 (in Greek), http:// www.emprosnet.gr/emprosnet-archive/619acdae-5dbb-46cc-af63-ef878c3f8555 [access: 22.12.2015].

Economou A., Material Culture: Theory, methodology, valorization, Athens 2014 (in Greek).

Eolis - Company of the Cultural Development of Lesvos, Guide to the Museums of Lesvos. Museums, Collections, Exhibitions, Libraries, Galleries, Mytilene 2006.

Fessa-Emmanouil E., The problem of cultural policy in Greece, "Issues of Space \& Arts" 1978, 9, pp. 59-65 (in Greek).

Gizelis G., Antonakopoulou I., Gardiki O., Kalpoutzi E., Laskaratou Ch., Organisation and Space Distribution of Greek Folklore Museums and Collections, Report, Vol. 1, Athens 1979 (in Greek).

Graham B., Ashworth G.J., Tunbridge J.E., A Geography of Heritage: Power, Culture and Econo$m y$, London 2000.

Hadjinikolaou T., Introduction [in:] C. Gougouli, T. Hadjinikolaou (Eds.), Special Volume: Museums and Folk Culture, "Ethnographica" 2003, 12-13, pp. 11-26 (in Greek).

Harrison R. (Ed.), Understanding the Politics of Heritage. Manchester 2010.

Morris A., Community capital: definition, [n.d.], http://www.learningtogive.org/resources/community-capital [access: 2.01.2016].

National Historical Museum, http://www.nhmuseum.gr/el/poioi-eimaste/i-istoriki-kai-ethnologikietaireia-tis-ellados/ [access: 2.01.2016].

Ntaflou Ch., Donateurs et musées dans la Grèce contemporaine [in:] D. Poulot (Ed.), Goûts privés et enjeux publics dans la patrimonialisation XVIIIe-XXIe siècle, Sorbonne Publications/coll. Histo. Art - 4, 2012, pp. 139-160.

Voudouri D., State and Museums: The institutional framework of archaeological museums, Athens 2003 (in Greek).

Waterton E., Watson St., Heritage as a focus of research: past, present and new directions [in:] E. Waterton, St. Watson (Eds.), The Palgrave Handbook of Contemporary Heritage Research, London 2011.

Weiner A., Inalienable Possessions: the paradox of keeping-while giving, Berkeley 1992. 